\title{
PENINGKATAN HASIL BELAJAR PENDIDIKAN AGAMA HINDU DAN BUDI PEKERTI MELALUI PEMBELAJARAN SAINTIFIK BERBASIS PETA KONSEP
}

\author{
I Nengah Suatra \\ Pendidikan Agama Hindu SMK Negeri 4 Bangli, Dinas Pendidikan dan Kebudayaan \\ Provinsi Bali \\ e-mail: inengahsuatra2@gmail.com
}

\begin{abstract}
Tujuan penelitian ini adalah untuk mendeskripsikan implementasi pembelajaran saintifik berbasis peta konsep dalam meningkatkan hasil belajar Pendidikan Agama Hindu dan Budi Pekerti. Penelitian ini merupakan penelitian tindakan kelas (PTK) yang dilakukan dalam 3 (tiga) siklus dengan masing-masing siklus terdiri atas empat tahapan yaitu: (1) perencanaan, (2) tindakan, (3) observasi/evaluasi, dan (4) refleksi. Penelitian ini dilakukan pada siswa kelas X AP SMK Negeri 4 Bangli tahun pelajaran 2017/2018 semester 1. Data penelitian ini berupa data hasil belajar Pendidikan Agama Hindu yang dikumpulkan melalui tes tertulis. Instrumen pengumpulan data berupa tes hasil belajar. Data dianalisis secara deskriptif yaitu data dilakukan perhitungan kuantitatif dan dideskripsikan untuk memperoleh gambaran hasil penelitian. Hasil penelitian menunjukkan bahwa implementasi pembelajaran saintifik berbasis peta konsep dapat meningkatkan hasil belajar Pendidikan Agama Hindu dan Budi Pekerti siswa kelas X AP SMK Negeri 4 Bangli tahun pelajaran 2017/2018. Hal ini ditunjukkan oleh perbandingan rerata nilai hasil belajar dari prasiklus ke siklus I meningkat sebesar 11,54 poin, dari prasiklus ke siklus II meningkat sebesar 15,77 poin, dari siklus I ke siklus II meningkat sebesar 4,23 poin.
\end{abstract}

Kata Kunci : Model pendekatan saintifik, peta konsep, hasil belajar Pendidikan Agama Hindu.

\begin{abstract}
The purpose of this study is to describe the implementation of scientific learning based on maps concepts in improving the learning outcomes of Hindu and Character Education. This research is a classroom action research (CAR) conducted in 3 (three) cycles with each cycle consisting of four stages, namely: (1) planning, (2) action, (3) observation / evaluation, and (4) reflection. This research was conducted at class X AP students of State Vocational School 4 Bangli at first semester in 2017/2018 academic year. The data of this study were data on learning outcomes of Hindu Education collected through a written test. The instrument of data collection is in the form of test. The data were analyzed descriptively; the data were carried out quantitative calculations and described to obtain an overview of the results of the study. The results showed that the implementation of concept-based scientific learning can improve the learning outcomes of Hindu and Character Education students of class X AP SMK Negeri 4 Bangli academic year 2017/2018. This is indicated by a comparison of the average value of learning outcomes from pre-cycle to cycle I increasing by 11.54 points, from precycle to cycle II increasing by 15.77 points, from cycle I to cycle II increasing by 4.23 points.
\end{abstract}

Keywords: Scientific approach model, concept map, learning outcomes of Hinduism Education.

\section{Pendahuluan}


Dalam implementasinya di lapangan Pendidikan Agama Hindu dan Budi Pekerti memiliki karakteristis khas dan mengakomodir budaya-budaya setempat menjadi bahan dan media belajar, sehingga diperlukan upaya-upaya maksimal dan semangat yang kuat bagi seorang pendidik dalam mengimplementasikan Pendidikan Agama Hindu ke dalam proses pembelajaran. Pembelajaran Pendidikan Agama Hindu menggunakan pola pendekatan terpadu, demokratis, humanistis, fungsional, dan kontekstual sesuai dengan dinamika perkembangan berbangsa dan bernegara serta tuntutan masyarakat modern yang pluralistic dan turbulent.

Namun pada kenyataannya implementasi kegiatan pembelajaran di sekolah dirasa masih belum sesuai harapan. Hal ini terbukti dengan masih rendahnya hasil belajar Pendidkan Agama Hindu dan Budi Pekerti. Berdasarkan hasil tes ulangan harian mata pelajaran Pendidikan Agama Hindu dan Budi Pekerti di kelas X AP SMK Negeri 4 Bangli tahun pelajaran 2017/2018 semester 1 menunjukkan bahwa dari 26 orang siswa, hanya 5 orang yang dapat nilai di atas Kreteria Ketuntasan Minimal (KKM) sebesar 70 dan 21 orang belum dapat mencapai KKM. Ini berarti bahwa ada 21 orang siswa yang masih mengalami kesulitan dalam pembelajaran Pendidikan Agama Hindu dan Budi Pekerti. Untuk mengatasi permasalahan tersebut guru hendaknya membantu siswa dalam pembelajaran dengan mengkondisikan pembelajaran yang menarik dan menyenangkan. Salah satu tindakan yang dapat dilakukan guru adalah dengan memilih strategi pembelajaran yang cocok serta menggunakan berbagai metode pembelajaran yang mampu mengembangkan iklim pembelajaran yang kondusif bagi siswa untuk belajar.

Di dalam kurikulum 2013 dinyatakan bahwa proses pembelajaran merupakan proses ilmiah. Karena itu kurikulum 2013 mengamanatkan esensi pendekatan ilmiah (scientific approach) dalam pembelajaran, yaitu pembelajaran yang mengarahkan kegiatan-kegiatan mengamati, mencoba, menanya, menalar atau mengasosiasikan, membentuk jejaring atau mengomunkasikan. Pendekatan scientific diyakini dapat mengembangkan sikap, keterampilan, dan pengetahuan siswa (Depdiknas, 2005: 7). Bagi siswa agar dapat mengamalkan pengetahuan agama khususnya, mereka hendaknya memiliki pemahaman dan penghayatan yang bersifat permanen terhadap apa yang dipelajari. Untuk memperoleh pemahaman konsep seperti itu diperlukan pengalaman belajar yang memberikan kesempatan siswa berpartisipasi aktif dalam pembelajaran.

Sufairoh (2016) menyatakan bahwa di dalam Kurikulum 2013 yang sekarang mulai diterapkan di sebagian sekolah-sekolah piloting ada dikenal namanya istilah Pendekatan Saintifik. Secara Istilah pengertian dari pendekatan saintifik adalah proses pembelajaran yang dirancang sedemikian rupa agar peserta didik secara aktif mengonstruk konsep, hukum atau prinsip melalui tahapan-tahapan mengamati (untuk mengidentifikasi atau menemukan masalah), merumuskan masalah, mengajukan atau merumuskan hipotesis, mengumpulkan data dengan berbagai teknik, meng-analisis data, menarik kesimpulan dan mengomunikasikan konsep

Pendekatan saintifik mengarahkan siswa dalam belajar aktif dalam menggali ilmu untuk dirinya. Dalam pembelajaran yang diharapkan terjadinya proses siswa yang mencari ilmu, bukan proses menstranfer ilmu dari guru ke siswa. Guru hanya sebagai fasilitator maupun mediator.Oleh karena itu dalam penelitian ini akan diterapkan pendekatan saintifik dalam upaya peningkatan hasil belajar Agama Hindu.

Dalam implementasi pendekatan saintifik, siswa memperoleh pengetahuan melalui pengalaman belajar yang aktif. Agar pengetahuan yang diperoleh siswa dapat lebih terkonstruksi dalam benaknya, maka pengetahuan tersebut hendaknya lebih sistematis. Sistematika suatu konsep diperlukan adanya pola-pola tertentu, seperti suatu bentuk peta konsep. Maka dari itu, peneliti berkeinginan mengkombinasikan metode peta konsep dalam penerapan pembelajaran pendekatan saintifik. Untuk itu, dalam penelitian tindakan kelas ini peneliti akan melakukan penelitian dengan implementasi pendekatan saintifik yang berbasis peta konsep dalam meningkatkan hasil belajar Pendidikan Agama Hindu dan Budi Pekerti siswa. 
Menurut penelitian yang dilakukan oleh Linda Fatmawati (2016) menyatakan bahwa terdapat perbedaan yang signifikan hasil belajar siswa pada kelas ekspeimen yang menerapkan pendekatan saintifik, dengan hasil belajar siswa yang menerapkan pendekatan konvensional pada kompetensi dasar fungsi manajemen siswa kelas $X$ di SMA Negeri 4 Jember Tahun Ajaran 2016/2017. Hasil belajar siswa menunjukkan ada perbedaan yang signifikan antara kelas yang menerapkan pendekatan saintifik dengan kelas yang menerapkan pendekatan konvensional, dimana hasil belajar siswa pada kelas yang menerapkan pendekatan saintifik lebih tinggi dibandingkan kelas yang menerapkan pendekatan konvensional

\section{Metode}

Penelitian ini lebih memfokuskan pada penerapan belajar konstruktivisme (constructivism learning model) pada pembelajaran Pendidikan Agama Hindu tentang "Ajaran Upaveda". Kurt Lewin merupakan perintis adanya penelitian tindakan untuk meningkatkan kinerja. Penelitian tindakan kelas ini dilakukan di SMK Negeri 4 Bangli. Siswa yang ada di sekolah tersebut pada tahun pelajaran 2017/2018 cukup banyak terbagi ke dalam beberapa kelas dengan rata-rata kemampuan akademiknya masih terasa di bawah standar. Hal ini dapat dilihat dari hasil belajar siswa yang secara keseluruhan masih belum sesuai harapan. Penelitian tindakan kelas ini dilaksanakan pada semester 1 tahun pelajaran 2017/2018 dengan implementasi pembelajaran mulai minggu ketiga bulan Agustus sampai minggu ketiga bulan Oktober tahun 2017. Subjek penelitian ini adalah semua siswa kelas $X$ AP SMK Negeri 4 Bangli yang berjumlah 26 orang. Kelas ini dipilih, mengingat kelas ini yang terdiri atas 21 laki-laki dan 5 perempuan, memiliki heterogenitas baik dari segi kecerdasan intelektual maupun kehidupan ekonomi sosialnya. Kemampuan akademiknya ada yang tergolong pintar, sedang, dan ada juga yang tergolong masih rendah. Objek penelitian ini adalah hasil belajar Pendidikan Agama Hindu dan Budi Pekerti. Hasil Belajar yang dimaksudkan adalah salah satu hasil dari proses pembelajaran yang diukur setelah proses pembelajaran dilakukan dengan pemberian tes tertulis. Penelitian tindakan kelas ini dilakukan dalam 3 (tiga) siklus dengan masing-masing siklus terdiri atas empat tahapan yaitu: (1) perencanaan, (2) tindakan, (3) observasi/evaluasi, dan (4) refleksi.

Data tentang hasil belajar siswa dikumpulkan melalui pemberian tes hasil belajar dalam posttest yang diadakan setelah selesai kegiatan pembelajaran tiap siklus sesuai materi pelajaran yang dibelajarkan dengan pendekatan saintifik. Instrumen pengumpulan data hasil belajar berupa tes hasil belajar. Data hasil penelitian dianalisis secara deskriptif. Analisis deskriptif digunakan untuk mendeskripsikan nilai rata-rata atau mean (M) dan standar deviasi (SD), daya serap siswa (DSS), serta ketuntasan klasikal (KK). Data yang diperoleh berupa data kuantitatif yaitu data hasil belajar dari hasil posttest. Selanjutnya, untuk mengetahui tingkat hasil belajar siswa maka nilai-nilai yang berhasil dicapai masing-masing siswa dikonversi ke dalam kualifikasi berdasarkan pada patokan-patokan yang ditetapkan sesuai pedoman konversi pada nominasi relatif Penilaian Acuan Patokan (PAP).

\section{Hasil dan Pembahasan}

Studi awal dilakukan peneliti dalam pelaksanaan pembelajaran di kelas X AP pada semester I tahun 2017/2018 dalam pembelajaran Pendidikan Agama Hindu. Dalam pembelajaran tersebut diterapkan model pembelajaran konvensional dengan metode diskusi, tanya jawab, maupun pemberian tugas seperti biasa. Dalam pembelajaran tersebut nampaknya kurang adanya peran serta aktif siswa, guru lebih mendominir, serta masih diwarnai dengan adanya transfer ilmu dari guru ke siswa.

Hasil belajar Pendidikan Agama dilihat dari hasil tes tertulis yang diberikan setelah perlakuan pembelajaran Pendidikan Agama Hindu. Dari hasil analisis data hasil belajar itu siswa pada refleksi awal, terlihat bahwa nilai terendah adalah 30,00 dan nilai tertinggi adalah 80,00 . Persentase siswa yang belum tuntas adalah $69 \%$ (118 orang), sedangkan persentase 
banyaknya siswa yang sudah tuntas adalah $31 \%$ (8 orang). Distribusi hasil belajar Pendidikan Agama siswa pada prasiklus dapat dilihat pada Gambar 1 berikut ini.

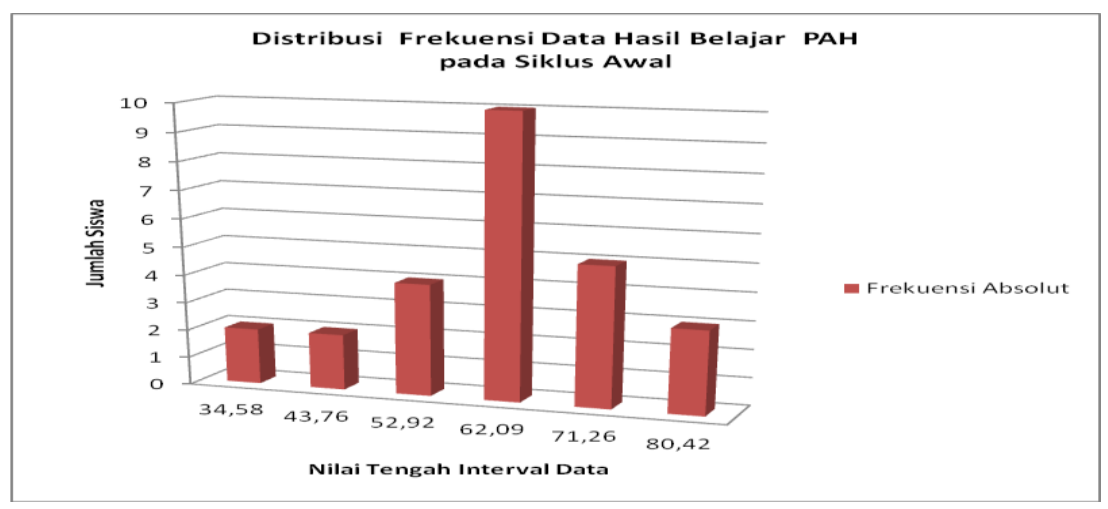

Gambar 1. Diagram Distribusi Data Hasil Belajar Pendidikan Agama Hindu dan Budi Pekerti pada Siklus Awal

Berdasarkan tes hasil belajar Pendidikan Agama Hindu yang diberikan, jumlah total nilai hasil belajar Pendidikan Agama Hindu adalah 1.585 dengan banyaknya siswa adalah 26 orang sehingga rata-rata nilai hasil belajar PAH siswa adalah 60,69. Daya serap siswa secara klasikal pada refleksi awal adalah $61 \%$, dan ketuntasan belajar siswa secara klasikal adalah $31 \%$. Data tersebut menunjukkan bahwa rata-rata nilai hasil belajar Pendidikan Agama Hindu siswa belum memenuhi KKM yang telah ditetapkan yaitu 70 . Selain itu, daya serap dan ketuntasan belajar siswa secara klasikal juga belum memenuhi kriteria yang telah ditetapkan pada indikator keberhasilan.

Tindakan pada siklus I dilaksanakan dalam tiga kali pertemuan yaitu dua kali pertemuan untuk pelaksanaan tindakan dan satu kali pertemuan untuk pelaksanaan tes hasil belajar. Rata-rata nilai hasil belajar siswa pada siklus I adalah 72,50, daya serap siswa secara klasikal adalah $72 \%$, dan ketuntasan belajar siswa secara klasikal adalah $77 \%$. Jumlah siswa yang tuntas pada siklus I adalah 20 siswa dan belum tuntas 6 orang. Berdasarkan analisis data tersebut, dapat disimpulkan bahwa hasil pelaksanaan tindakan pada siklus I belum memenuhi indikator keberhasilan yang telah ditetapkan, meskipun nilai rata-rata hasil belajar dan daya serap sudah memenuhi criteria namun ketuntasan belajar belum mencapai $80 \%$.

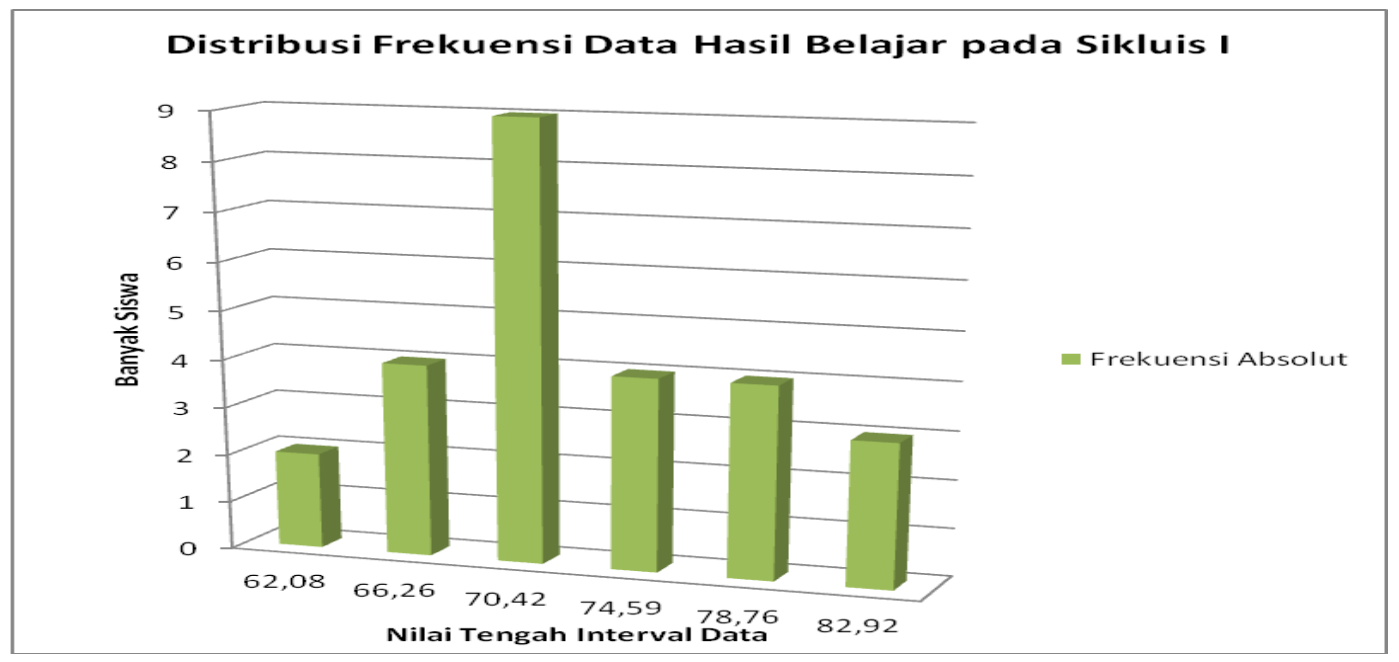

Gambar 2. Diagram Distribusi Data Hasil Belajar Pendidikan Agama Hindu dan Budi Pekerti pada Siklus I 
Dalam pelaksanaan siklus I masih ditemukan beberapa permasalahan dalam proses pembelajaran yang perlu dijadikan pertimbangan dalam pelaksanaan tindakan pada siklus berikutnya. Berdasarkan kegiatan observasi/evaluasi I, terungkap beberapa permasalahan yang menyebabkan belum tuntas dan belum optimalnya pembelajaran pada siklus I, yaitu sebagai berikut. (1) Keseriusan dan kesiapan siswa dalam mengikuti pembelajaran masih kurang. Ketika pembelajaran berlangsung, masih terlihat siswa yang bermain-main. Untuk mengatasi hal tersebut, guru berulang kali memperingatkan bahwa aktivitas siswa selama proses pembelajaran juga dinilai dan secara terbuka guru mengungkapkan aspek-aspek yang dinilai. (2) Siswa kurang aktif bertanya saat pembelajaran berlangsung. Hal ini dikarenakan siswa tidak terbiasa berdiskusi dan mengungkapkan gagasannya. (3) Pembelajaran berlangsung kurang terkendali, siswa ribut dalam bekerja pada kelompoknya masing-masing. Siswa belum terbiasa bekerja dan berdiskusi dalam kelompok. Dalam proses diskusi ada siswa yang enggan untuk berdiskusi dengan teman sekelompoknya saat menjawab permasalahan yang ada dalam LKS. Beberapa anggota kelompok masih bekerja sendiri-sendiri tanpa berdiskusi dalam menyelesaikan permasalahan yang ada pada LKS. (4) Siswa yang mempunyai kemampuan akademik rendah, tidak berani mengungkapkan pendapatnya dan siswa yang memiliki kemampuan akademik tinggi cenderung ragu-ragu untuk memberikan penjelasan kepada temannya. Guru kesulitan membimbing siswa dalam diskusi kelompok. Ini dikarenakan guru tidak terbiasa menggunakan kelompok dalam pembelajaran sehingga pada saat kerja kelompok banyak siswa yang tidak bisa bekerja dengan baik. Pada saat membimbing kelompok, siswa sering menanyakan hal-hal yang semestinya mereka bisa kerjakan, tanpa ada usaha terlebih dahulu dari kelompok tersebut mengerjakan LKS secara mandiri. (5) Siswa belum terbiasa di depan kelas untuk menjelaskan hasil pekerjaannya sehingga ketika di depan mereka masih membaca buku catatan atau lembaran tugasnya. Untuk mengatasi hal tersebut, guru memberikan arahan cara menjelaskan yang baik agar tidak membaca secara monoton; (6) Perwakilan kelompok yang menjelaskan hasil diskusi di depan kelas monoton hanya siswa yang pintar dalam kelompoknya. Oleh karena itu, untuk pertemuan selanjutnya guru memberikan kesempatan pada siswa yang berbeda untuk memaparkan hasil kerja kelompoknya sehingga peluang siswa untuk mengandalkan teman yang lebih mampu dapat dikurangi dan membelajarkan siswa untuk berani dalam mengemukakan pendapatnya; (7) Siswa kurang disiplin dalam mengerjakan tugas kelompok dan tes evaluasi pada akhir pertemuan. Ada beberapa kelompok yang tidak mengumpulkan tugas pada waktu yang telah ditentukan. Oleh karena itu, guru memberitahukan kepada siswa bahwa ketepatan dalam mengumpul tugas juga merupakan salah satu aspek yang dinilai. Begitupula dalam pengerjaan tes evaluasi, siswa cenderung meremehkan soal-soal tes evaluasi yang diberikan.

Berdasarkan hasil tes hasil belajar pada siklus I, diperoleh bahwa nilai rata-rata hasil belajar siswa masih belum mencapai hasil yang maksimal serta ketuntasan belajar masih perlu dimaksimalkan lagi. Hal tersebut terjadi karena beberapa hal, yaitu sebagai berikut. (a) Siswa belum terbiasa diberikan soal dalam bentuk uraian dengan cepat sesuai waktu yang telah ditentukan; (b) Siswa belum bisa memaparkan jawaban yang dipilih secara tepat ini menunjukkan konsep dasar yang dimiliki siswa masih lemah; (c) Siswa belum bisa menjawab dengan langkah yang tepat. Kebanyakan siswa masih bingung menentukan salah satu jawaban yang tepat dari beberapa jawaban yang tersedia. (d) Kemampuan investigasi siswa juga masih lemah. Kebanyakan dari mereka masih sekedar menebak tanpa melakukan pengamatan dan investigasi secara mendalam; (e) Siswa belum memanfaatkan diskusi kelompok dan LKS secara maksimal sehingga pembelajaran masih berpusat pada individu masing-masing siswa. Kondisi heterogen siswa dengan kemampuan akademik yang berbeda seperti ini tentu perlu dikurangi karena tujuan pembelajaran kelompok yaitu saling bertukar pikiran dalam menyelesaikan masalah.

Tindakan pembelajaran pada siklus II dilaksanakan dalam tiga kali pertemuan, yaitu dua kali pertemuan untuk pelaksanaan tindakan dan satu kali pertemuan untuk pelaksanaan tes hasil belajar. Sebaran hasil belajar siswa pada siklus II dapat dilihat pada Gambar 3. 


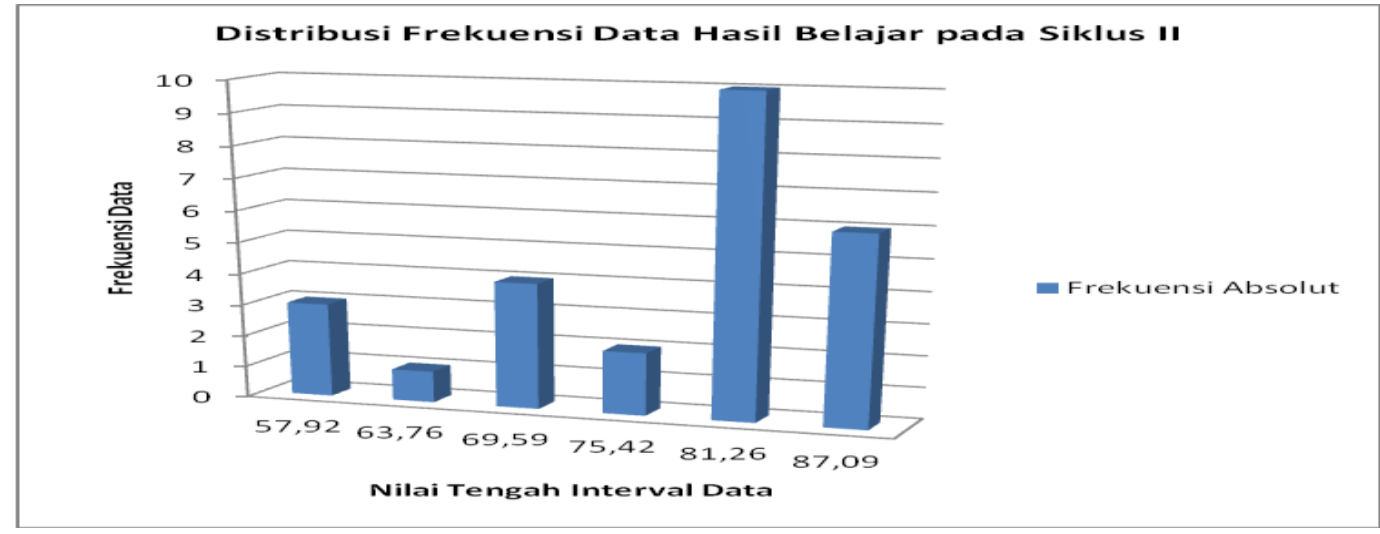

\section{Gambar 3. Diagram Frekuensi Data Hasil belajar PAH dan Budi Pekerti Siswa pada Siklus II}

Dari hasil analisis data hasil belajar siswa pada siklus II terlihat bahwa nilai terendah adalah 60 dan skor tertinggi adalah 90. Terlihat bahwa siswa yang tuntas (memperoleh skor $\geq 80$ ) yaitu 22 orang dan 4 orang yang belum tuntas.

Dapat disimpulkan bahwa hasil pelaksanaan tindakan pada siklus II telah memenuhi kriteria keberhasilan yang telah ditetapkan, yaitu rata-rata hasil belajar PAH siswa 76,73. Daya serap siswa secara klasikal lebih dari $70 \%$, yaitu sebesar $77 \%$ dan ketuntasan belajar siswa secara klasikal lebih dari $80 \%$, yaitu sebesar $85 \%$. Rata-rata hasil belajar siswa pada siklus I, yaitu 72,50 dan rata-rata hasil belajar siswa pada siklus II, yaitu 76,73. Berdasarkan refleksi yang telah dilaksanakan dan dengan memperhatikan hasil yang didapatkan, terlihat kelebihan-kelebihan dari tindakan yang telah dilaksanakan pada siklus II, yaitu sebagai berikut. (a) Keseriusan dan kesiapan siswa dalam mengikuti pembelajaran sudah terlihat baik. Ketika pembelajaran berlangsung, siswa sudah menyiapkan alat tulis termasuk buku sumber belajar. Siswa juga tidak bermain-main dalam belajar. Ini disebabkan ketertarikan siswa dalam menggunakan media pembelajaran yang diberikan oleh guru; (b) Siswa lebih aktif bertanya saat pembelajaran berlangsung. Untuk meningkatkan kemampuan siswa dalam bertanya, guru sering memberikan pertanyaan-pertanyaan pancingan pada siswa sehingga siswa lebih yakin untuk mengemukakan pendapatnya; (c) Pada siklus II terlihat bahwa masing-masing individu dalam kelompok sudah saling mengisi. Dalam hal ini tentu saja guru telah menyampaikan tujuan pembelajaran kelompok. Terlihat bahwa beberapa siswa telah mampu menjelaskan suatu konsep atau menyampaikan pemecahan masalah pada temannya dalam satu kelompok; (d) Guru tidak mengalami kesulitan lagi dalam membimbing siswa dalam diskusi kelompok. Siswa juga tidak lagi mengalami kesulitan dalam mengerjakan tugas secara mandiri ataupun kelompok. Siswa sudah mencoba terlebih dahulu untuk menyelesaikan soal-soal yang diberikan secara mandiri; (e) Siswa terlihat lebih berani dalam menyampaikan pendapat ataupun untuk mempresentasikan hasil diskusinya dengan bahasa atau cara mereka sendiri. Bahkan siswa berlomba untuk bisa maju ke depan menjawab pertanyaan yang diajukan oleh guru; (f) Keantusiasan dan keaktifan siswa sudah menunjukkan peningkatan. Hal ini dapat dilihat ketika kegiatan menjelaskan kembali banyak siswa yang ingin bertanya dan menanggapi pertanyaan yang diajukan temannya. Pada tahap awal, ada keengganan kelompok siswa yang kurang aktif untuk menyampaikan pendapatnya sehingga terkesan diskusi didominasi oleh kelompok siswa yang terbiasa berpendapat. Pada pertemuan selanjutnya, partisipasi siswa dari kelompok kurang aktif semakin menurun, walaupun siswa yang kemampuannya baik masih mendominasi pembelajaran.

Berdasarkan hasil tes hasil belajar siswa pada siklus II terlihat adanya perbaikan yang dimiliki siswa dalam menyelesaikan masalah-masalah $\mathrm{PAH}$. Hal ini disebabkan beberapa hal diantaranya sebagai berikut. (a) Pemahaman siswa terhadap materi yang telah diberikan dan aktivitas siswa dalam menyelesaikan berbagai soal hanya terbatas pada 
materi dan latihan soal yang ada di buku dan LKS saja. Jika guru memberikan soal yang berbeda, maka siswa tidak akan mampu menjawabnya. Terkait dengan masalah tersebut, guru menekankan pada siswa bahwa kegiatan pembelajaran tidak boleh hanya terpaku pada sumber ajar dan LKS yang ada di sekolah saja. Siswa diharapkan mampu menggali berbagai informasi lain dan terus mencoba menyelesaikan masalah-masalah $\mathrm{PAH}$ yang terkait materi yang telah dipelajari; (b) Walaupun masih terlihat ada siswa yang belum tepat menentukan jawaban dari soal uraian yang diberikan, beberapa siswa sudah terlihat mampu memberikan penjelasan yang tepat terhadap permasalahan yang diberikan. Mulai dari sistematika penyelesaian masalah dan pemilihan konsep yang tepat dengan masalah yang diberikan. Oleh karena itu, tindakan guru selanjutnya adalah lebih menuntun siswa dengan langkah penyelesaian yang tepat tanpa mengubah cara atau pengetahuan awal yang dimiliki oleh siswa. Untuk langkah-langkah penyelesaian soal siswa yang keliru, guru menekankan cara penyelesaian soal yang sistematis sesuai tahapan pembelajaran investigasi. Dengan konsep dasar yang baik dan latihan yang maksimal memungkinkan siswa mampu menyelesaikan segala permasalahan yang mereka temukan.

Berdasarkan analisis data tersebut, hasil yang dicapai pada siklus II telah memenuhi semua indikator keberhasilan yang diharapkan. Perbaikan tindakan pada siklus II telah membuat perubahan terhadap proses pembelajaran sehingga menjadi lebih kondusif. Perbaikan-perbaikan yang dilakukan ternyata mampu memberikan hasil yang baik dimana hasil tes hasil belajar PAH siswa pada siklus II sudah memenuhi indikator keberhasilan yang telah ditetapkan. Secara umum, siswa telah mampu menyelesaikan permasalahan yang diberikan. Hal ini ditunjukkan dari antusias siswa dalam menjawab masalah yang diberikan. $\mathrm{Hal}$ ini juga disebabkan oleh adanya pendekatan secara saintifik seperti pemberian peran aktif siswa utnuk menemukan sendiri jawaban atas permasalahan sehingga dapat menumbuhkan rasa percaya diri siswa. Dengan rasa percaya diri ini, siswa memiliki motivasi untuk belajar PAH. Hal ini sesuai dengan hakikat belajar dimana siswa cenderung belajar dengan baik kalau mereka termotivasi. Adanya motivasi merupakan faktor dari dalam diri siswa yang dapat meningkatkan hasil belajar $\mathrm{PAH}$.

Adanya motivasi siswa ini sangat dimungkinkan karena pembelajaran saintifik yang menuntut siswa untuk berperan aktif dalam pembelajaran. Di sini siswa sebagai pusat pembelajaran (student center) yang diberikan kesempatan seluas-luasnya untuk menggali pengetahuannya sendiri melalui berbagai sumber, media, serta membentuk jejaring (berdiskusi dengan temannya). Siswa tidak diberi tahu jawaban atas permasalahan yang dihadapi, tetapi siswa diarahkan untuk mencari tahu jawaban sendiri atas permasalahan yang dihadapi. Siswa akan dapat mengkonstrusikan informasi di benaknya menjadikan pengetahuan (menurut pandangan paham konstruktivis). Dengan menemukan sendiri jawabannya, maka penegtahuan tersebut akan bertahan lebih lama di benaknya. Adanya fenomena seperti itu siswa akan merasa lebih percaya diri untuk terus aktif dalam pembelajaran yang akan mendorong rasa penasaran sehingga menjadikan termotivasi.

Peta konsep dapat memberikan alur pikiran dan sebagai kerangka berpikir siswa dalam menemukan konsep-konsep yang dipelajari. Peta konsep membentuk pola piker yang sistematis karena memberikan arah kemana harus berpikir. Jadi, peta konsep di dalam pembelajaran saintifik dapat mempermudah siswa dalam memahami apa yang dipelajari, sehingga pembelajari ini dapat meningkatkan hasil belajar siswa.

Adapun perubahan-perubahan yang terjadi adalah sebagai berikut. (a) Siswa sudah mampu menyelesaikan masalah-masalah PAH. Walaupun tidak secara keseluruhan, beberapa siswa telah mampu memberikan solusi atas masalah-masalah PAH yang diberikan oleh guru; (b) Siswa telah menjelaskan jawaban dari masalah yang diberikan oleh guru dengan memperhatikan sistematika penyelesaiannya. Siswa terlihat melakukan investigasi pemecahan masalah dari berbagai soal yang diberikan. Ini menunjukkan bahwa model pembelajaran yang diberikan memberikan pengaruh positif pada pembelajaran; (c) Walaupun masih terlihat ada siswa yang belum tepat menentukan jawaban, beberapa siswa sudah terlihat mampu memberikan penjelasan yang tepat terhadap permasalahan yang diberikan. Mulai dari sistematika penyelesaian masalah dan pemilihan konsep yang tepat dengan masalah yang diberikan; (d) Secara umum siswa telah terlihat memanfaatkan diskusi 
kelompok dan komunikasi secara maksimal. Hampir sebagian besar siswa bertanya dan aktif dalam kegiatan diskusi kelompok.

Berdasarkan fenomena pada pelaksanaan siklus I, dapat disimpulkan bahwa pendekatan saintifik berbasis peta konsep telah dapat diterapkan secara optimal. Pada kenyataannya siswa telah dapat mengembangkan gagasannya namun belum mampu berinteraksi dengan teman sebayanya sehingga telah tercipta suasana diskusi yang akan membuat siswa berdialog untuk saling menanggapi jawaban dan saling bertukar pendapat.

Perbaikan tindakan yang dilakukan adalah sebagai berikut: (a) Guru berulang kali memperingatkan bahwa aktivitas siswa selama proses pembelajaran juga dinilai dan secara terbuka guru mengungkapkan aspek-aspek yang dinilai; (b) Guru menekankan kepada siswa bahwa apapun jawaban, masukan, pertanyaan yang dikemukakan akan dinilai oleh guru. Untuk meyakinkan siswa, guru memperlihatkan secara langsung skor yang mereka peroleh sehingga siswa menjadi termotivasi untuk mengemukakan gagasannya; (c) Menyampaikan pada siswa bahwa tujuan dibentuknya kelompok adalah memfalisistasi seluruh kemampuan akademik siswa yang ada pada kelompok. Untuk itu, pembelajaran hendaknya terjadi secara merata. Dalam artian, siswa yang memiliki kemampuan akademik tinggi membimbing siswa yang memiliki kemampuan akadekik rendah dan begitupula sebaliknya siswa yang memiliki kemampuan akademik rendah tidak ragu-ragu bertanya pada temannya yang memiliki kemampuan akademik tinggi; (d) Guru memberikan arahan pada siswa cara menjelaskan atau memberikan suatu gagasan/ide yang baik dengan tidak berpatokan pada buku catatan dan buku paket. Siswa diminta menjelaskan suatu hal dengan menggunakan bahasanya sendiri dengan tetap beracuan pada konsep PAH; (e) Guru memberikan kesempatan pada siswa yang berbeda untuk memaparkan hasil kerja kelompoknya sehingga peluang siswa untuk mengandalkan teman yang lebih mampu dapat dikurangi dan membelajarkan siswa untuk berani dalam mengemukakan pendapatnya.

Perubahan-perubahan yang terjadi adalah sebagai berikut: (a) Guru mendata siswa yang tidak fokus dalam pembelajaran dan memberikan peringatan pada mereka bahwa aktivitas yang mereka lakukan akan mempengaruhi hasil belajar mereka selama ini; (b) Secara umum siswa telah mampu mengajukan pendapat walaupun masih ada yang tidak menggunakan bahasa formal; (c) Pada saat diskusi kelompok, siswa sudah terlihat saling mengisi antara satu dengan lainnya. Jadi, tidak ada kesenjangan antara siswa yang memiliki akademik tinggi dengan siswa yang memiliki akademik rendah; (d) Siswa terlihat telah mampu memberikan suatu gagasan/ide tanpa membawa buku catatan dan buku paket. Walaupun terbata-bata, mereka terus mencoba menyampaikan pandangan mereka terhadap masalah yang diberikan guru atau masalah seehari-hari yang mereka hadapi dengan menggunakan bahasa sendiri dengan tetap beracuan pada konsep PAH; (e) Dalam menyampaikan hasil diskusi kelompok, terlihat siswa yang menyampaikan diskusi bukan hanya siswa yang memiliki kemampuan akademik tinggi saja. Siswa yang memiliki kemampuan akademik rendah juga sudah terlihat berani dalam mengemukakan gagasan mereka. Ini dikarenakan guru memberikan kesempatan seluas-luasnya bagi siswa yang ingin mengajukan pandangan mereka terkait masalah yang diberikan oleh guru.

Berdasarkan uraian di atas dan peningkatan-peningkatan yang terjadi pada setiap siklus menunjukkan bahwa pembelajaran saintifik berbasis peta konsep telah berhasil meningkatkan hasil belajar Pendidikan Agama Hindu dan Budi Pekerti siswa kelas X AP SMK Negeri 4 Bangli Tahun Pelajaran 2017/2018.

\section{Simpulan dan Saran}

Berpijak atas hasil analisis data dapat disimpulkan bahwa implementasi pembelajaran saintifik berbasis peta konsep dapat meningkatkan hasil belajar Pendidikan Agama Hindu siswa kelas X AP SMK Negeri 4 Bangli Tahun Pelajaran 2017/2018 pada semester 1. Hal ini ditunjukkan oleh perbandingan rerata hasil belajar dari prasiklus ke siklus I meningkat sebesar 11,54 poin, dari prasiklus ke siklus II meningkat sebesar 15,77 poin, dari siklus I ke siklus II meningkat sebesar 4,23 poin. Berpijak atas simpulan yang sudah dikemukakan, dapat diajukan saran sebagai berikut : (1) Para guru Pendidikan Agama Hindu dapat 
mencoba pembelajaran pendekatan saintifik berbasis peta konsep; (2) Kepada Kepala Sekolah agar dapat memberi penekanan agar guru bersedia melaksanakan pembelajaran dengan langkah-langkah model yang sudah diteliti; (3) Dalam melaksanakan proses pembelajaran pada mata pelajaran Pendidikan Agama Hindu implementasi pembelajaran saintifik berbasis peta konsep semestinya menjadi pilihan dari beberapa strategi yang ada mengingat pembelajaran ini telah terbukti dapat meningkatkan kompetensi pengetahuan, keterampilan, maupun sikap; (4) Walaupun penelitian ini sudah dapat membuktikan efek utama dari pembelajaran saintifik berbasis peta konsep dalam meningkatkan hasil belajar, sudah pasti dalam penelitian ini masih ada hal-hal yang belum sempurna dilakukan, oleh karenanya kepada peneliti lain yang berminat meneliti topik yang sama untuk meneliti bagian-bagian yang tidak sempat diteliti.

\section{Daftar Pustaka}

Arikunto, Suharsimi; Suhardjono; Supardi. 2006. Penelitian Tindakan Kelas. Jakarta: PT Bumi Aksara.

Dahar, Ratna Wilis. 1989. Teori-Teori Belajar. Jakarta: Penerbit Erlangga.

Depdiknas. 2011. Membimbing Guru dalam Penelitian Tindakan Kelas. Jakarta: Pusat Pengembangan Tenaga Kependidikan Badan Pengembangan Sumber Daya Manusia Pendidikan Penjaminan Mutu Pendidik.

Dimyati dan Mudjiono. 2001. Belajar dan Pembelajaran. Jakarta: Dirjen Dikti.

Fatmawati Linda dkk. (2017). Perbedaan Hasil Belajar Siswa Melalui Pendekatan Konvensional Dengan Pendekatan Saintifik pada Kompetensi Dasar Fungsi Manajemen Siswa Kelas X di SMA Negeri 4 Jember Tahun Ajaran 2016/2017. Jurnal Pendidikan Ekonomi. Program Studi Pendidikan , Fakultas Keguruan dan Ilmu Pendidikan, Universitas Jember

Iskandar. 2011. Penelitian Tindakan Kelas. Jakarta: Gaung Persada (GP) Press.Kemendikbud. 2013. Materi Pelatihan Guru, Implementasi Kurikulum 2013. Jakarta: Kementerian Pendidikan dan Kebudayaan.

Kunandar.2009. Langkah Mudah Penelitian Tindakan Kelas Sebagai Pengembangan Profesi Guru. Jakarta: Rajawali Pers.

Muslich, Masnur. 2011. Melaksanakan PTK itu Mudah. Jakarta: PT. Bumi Aksara.

Maba, Wayan. 2002. Evaluasi Pembelajaran. Makalah yang disampaikan dalam penataran PBM Dosen Kopertis Wilayah VIII, Tanggal 27-30 Oktober 2002.

Nur, Mohamad et al. 2001. Teori Belajar. Surabaya: University Press.

Purwanto, Ngalim. 2011. Psikologi Pendidikan. Cetakan keduapuluhlimaPenerbit: PT Remaja Rosdakarya.Bandung

Purwanto, Ngalim. 2009. Prinsip-prinsip dan Teknik Evaluasi Pengajaran. Cetakan kelimabelas.Penerbit: PT Remaja Rosdakarya.Bandung

Slavin, Robert E. 1995.Cooperative Learning : Theory, Research, and Practice. Boston: Allyn and Bacon.

Sufairoh. 2016. Pendekatan saintifik \& model pembelajaran k-13. Jurnal pendidikan profesional, volume 5, no. 3, desember 2016.

Suyadi. 2010. Pemaduan Penelitian Tindakan Kelas. Jogjakarta: Diva Press. 
Soemanto, Wasty. 2001. Pengantar Psikologi Pendidikan. Surabaya: Usaha Nasional.

Soetomo. 1993. Dasar-Dasar Interaksi Belajar-Mengajar. Surabaya: Usaha Nasional.

Sudjana, Nana. 2002. Penilaian Hasil Proses Belajar Mengajar. Bandung: PT Remaja Rosdakarya.

Surya, Mohammad. 2004. Psikologi Pembelajaran dan Pengajaran. Bandung: Pustaka Bani Quraisy.

Trianto. 2007. Model-model Pembelajaran Inovatif Berorientasi Konstruktivistik. Konsep, Landasan Teoritis-Praktis dan Implementasinya. Perpustakan Nasional Katalog dalam Terbitan. Penerbit: Prestasi Pustaka Publisher. Jakarta.

Wina Sanjaya, H. 2011. Penelitian Tindakan Kelas. Jakarta: Prenada Media Group.

. 2014. Kurikulum 2013 : Langkah-langkah Pendekatan Saintifik. http://blog.undiksha.ac.id/partha-sindu/kurikulum-2013-langkah-langkahpendekatan-saintifik/

2015. Implementasi Pembelajaran Saintifik 5M. 02 September 2015 16:41:17 Diperbarui: 02 September 2015 16:42:04. http://www.kompasiana.com/ m yunus/implementasi-pembelajaran-saintifik-5m 55e6c43d9297737a14185a74

- Pengertian/Definisi Pendekatan Saintifik, Prinsip Pembelajaran Dan Langkah-Langkah Pembelajaran Dengan Pendekatan Saintifik Kurikulum 2013.

.2014. Pendekatan Saintifik Model Kurikulum 2013. http://www.blogwahyu.com/2014/06/pendekatan-saintifik-modelkurikulum.html\#sthash.zLSq7qXP.dpuf 